\title{
PROPENSITY TO MIGRATION IN THE CEEC: COMPARISON OF MIGRATION POTENTIAL IN THE CZECH REPUBLIC AND POLAND
}

\author{
Karolina Kowalska, Wadim Strielkowski*
}

\begin{abstract}
:
Together with mainly economic factors influencing the migration decisions, there is also a migration potential which is unique for every country and that largely pre-determines the outgoing migrations or labour mobility decisions. This paper compares the migration potential and migration decisions for the Czech Republic and Poland using the data for inter-regional and rural-urban migrations. These data that can be used as a proxy for migration potential, are very useful in predicting the propensity to international migration.

We come to conclusions that migration potential and the propensity to migrate as a reaction to worsening of the economic conditions at home are highly correlated. The comparative analysis shows that while Poles are quite sensitive to worsening economic conditions at home, Czechs posses lower value of migration potential and therefore are not so inclined to migrations. The results might explain the high volume of migration from Poland after the EU 2004 enlargement.
\end{abstract}

Keywords: economics of migration, labour mobility, migration potential, propensity to migration, Czech Republic, Poland

JEL Classification: F02, F22, J61

\section{Introduction}

The basis of economic theory dealing with the economics of migration states that the most important drivers of migration flows from a less wealthy country or region to a more wealthy one are wage differentials, economic disparities, differences in GDP per capita and unemployment differentials (see for example Hannan, 1970; Todaro, 1969; Harris and Todaro, 1970; Walsh, 1974, 1987; Strielkowski and O'Donoghue, 2006; Glazar and Strielkowski, 2010; Strielkowski, 2012). In addition, various social security systems might enter the picture and influence the scope of migration. For example, Cushing (1993), Faini et al. (1999) or de Haas (2005) demonstrate how social benefits for the unemployed might enhance or halter metropolitan or international migration.

* Karolina Kowalska, Faculty of Economic Sciences, University of Warsaw, Długa 44/50, 00-241 Warsaw, Poland (karolinakowalska@wne.uw.edu.pl); Wadim Strielkowski, Charles University in Prague, Faculty of Social Sciences, Institute of Economic Studies. Opletalova 26, 11000 Praha 1, Prague, Czech Republic and Global Change Research Centre AS CR, v.v.i,; Bělidla 4a, Brno 60300, Czech Republic (strielkowski@fsv.cuni.cz).

The authors are grateful for the support under the Grants No. P404/10/0581, No. AV0Z60870520 and No. CZ.1.05/1.1.00/02.0073. 
This paper argues that the scope and size of migrations strongly depend on the migration potential of population of a given country. For the population of countries with high migration potential it is more likely to react to the problems at home by increased emigration to the countries with higher income and lower unemployment (see for example Fidrmuc, 2002 or Glazar and Strielkowski, 2010). With regard to this, Strielkowski and Turnovec (2011) come with a concept of "indicator of migration costs" which is countryspecific and consists of tangible (e.g. cost of resettling or adjustment in the new country) and intangible (e.g. psychological costs of migration - breaking the social ties, leaving family or friends, language barrier) components. It can be shown that if this indicator is greater than the difference between wages of Member States in the common market, there is no motivation for the labour to move (propensity to migration equals to zero). In such a case economic and psychological costs of migration are larger than benefits of wage differentials. For the countries where the indicator is greater than wages, the migration potential (or the propensity to migration) is low and its citizens might not promptly react to wage and unemployment incentives abroad.

Our hypotheses are tested using the data from the two recent EU Member States: the Czech Republic and Poland (both joined the EU in 2004), with the former country being known for low volume of outgoing international migrations and the latter country representing quite the opposite case.

\section{Methodology \& Literature Review}

Migration potential and migration decisions are dependent on incentives and obstacles to migration. With regard to these incentives and obstacles, push (unbearable or threatening conditions in the home country) and pull factors (incentives in the host countries) play an important role (see Ravenstein, 1876, 1885; and Dorigo and Tobler, 1983). Incentives may represent higher remuneration, better employment opportunities, easier access to housing and/or favourable political or cultural environment. Obstacles to migration are usually represented by the difficulty of settling in at the new location, lack of information about distant opportunities, language barriers, transportation costs and visa restrictions for new immigrants.

The research literature on migration suggests that a very complex set of inter-relationships exists between social, psychological, structural and educational factors with the social background, as well as certain constraints on individual's migration decisions. Individual's motives or reasons for migrating require explanation. With regard to this, De Jong (1983) suggests that they are mainly explainable in terms of individual's locations in the economic and social structure, and level of educational background: because everything to what the individuals are aspiring to is given and pre-determined by their educational level and socialeconomic or socio-cultural characteristics. However, people's beliefs or perceptions about how satisfactory local or foreign communities are may depend also on the nature of the local economy or labour market (mainly on such factors as the rurality of the community and its unemployment level). Therefore, a direct linkage exists between the nature of the home community's economic structure and satisfying one's economic aspirations locally. 


\subsection{International and regional migration in the Czech Republic}

According to many sources, the Czech Republic is a country with low labour mobility (see for example Arltová and Langhamrová, 2010 or Stojanov, Strielkowski and Drbohlav, 2011). This concerns both inter-regional migrations and outward international migrations (Figure 1).

Prior to the EU accession in 2004, Czech outward migration flows were usually targeted for Germany and Austria as markets for its "surplus" labour with political and economic barriers preventing these migrations from becoming the large-scale flows. Legal employment of the Czech citizens after the collapse of the Iron Curtain was processed in several forms: seasonal works (up to three months per year), employment on the basis of agreements, bilateral employments with educational purposes and the so-called "pendling"' (VUPSV, 2001). "Pendling" or simply working in one country without residing there (a worker usually returns home every night and spends most of his earnings in the home country) existed on a large-scale in the first half of the 1990s (12,000 workers annually), however, by the end of the decade the number of Czech pendlers decreased by $60 \%$ (VUPSV).

Figure 1

Gross Migration Flows (permanent): the Czech Republic (1989-2010)

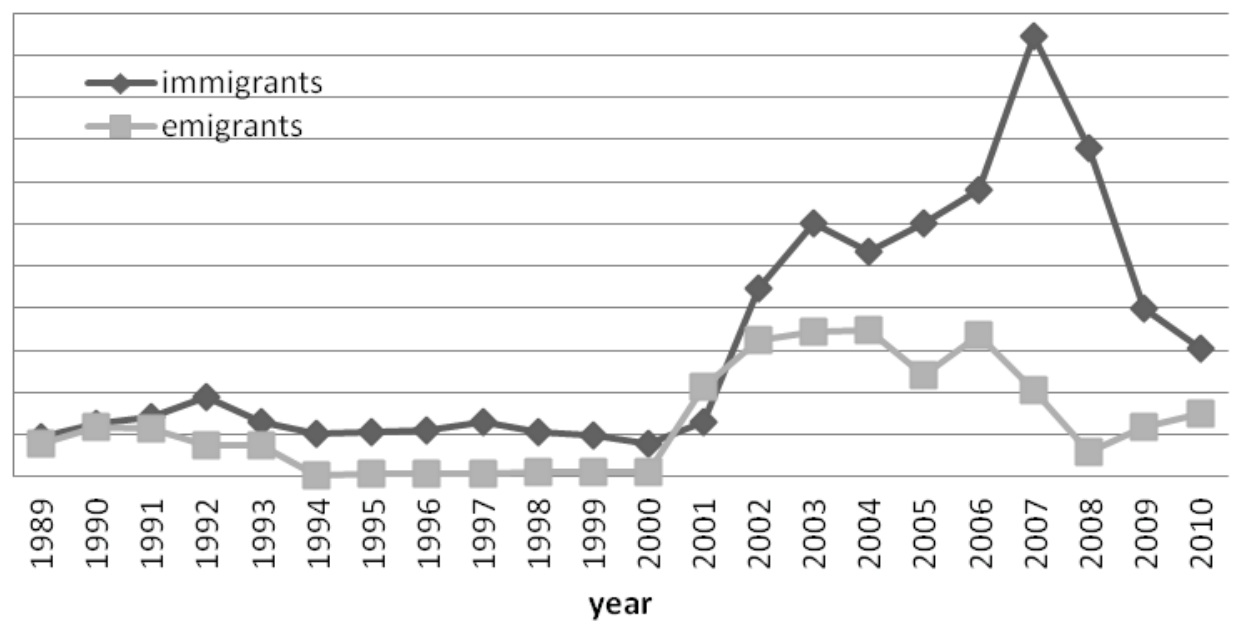

Source: Czech Statistical Office, 2012.

One of the reasons for that was, on the one hand, the decrease in issuing of working permits for Germany and Austria and, on the other hand, the loss of interest in low-paid and low-qualified jobs. According to Austrian statistics, prior to the EU 2004 enlargement, employees from the Czech Republic were merely $10 \%$ of the largest group of employees

1 i.e. commuting daily for abroad to work 
from the former Yugoslavia and yielded 10.8 thousand people in the 2002 (Austrian Labour Statistics, 2003). The second-largest group were the Turks and later followed by Hungary and Poland. The same situation could have been observed in Germany: in the 2002 Czech employees constituted 4\% (13.2 thousand persons) of the largest group of foreign employees - the Turks (German Labour Statistics, 2003). This comparisons show that under the equal treatment and labour law, only a small fragment of the Czech labour force was seeking employment abroad, even though the geographical proximity of the Czech Republic is considerably higher than for example in the case of Turkey. The situation did not change after Czech accession to the EU in 2004. For instance, in 2007 alone there were just 1,247 Czech coming to Austria and 988 leaving the country, with a net of 259 people (Austrian Labour Statistics, 2011).

One more important fact in international migrations is the level of human capital expressed by the knowledge of foreign languages. With the increasing popularity of English as lingua franca most of the young people from the Czech Republic are looking for employment opportunities in the EU English-speaking countries, which can also be used as an explanation of loosing interest in Austrian and German labour markets. Even though, the number of the Czechs in the United Kingdom, the country that opened its labour market to all new EU Member States in 2004, remains as low as 33 thousand people in 2011 (Office for National Statistics, 2011).

When it comes to regional migrations, the most important factor of accessing the country's migration potential, it can be stated that like any other post-communist country the Czech Republic has very low regional migration turnover in comparison with the "old" EU Member States (see Strielkowski and O’Donoghue, 2006; Drbohlav et al., 2010; Arltová and Langhamrová, 2010) and rather acts as the major "magnet" for international migrants among other CEE countries (Drbohlav et al., 2010). The reasons to the low regional mobility are mostly the housing-stock market and the cultural specifics (mostly granted employment in the communist times and thus tightness to the place of work and residence). Table 1 reports the numbers of international and regional migrants. It is apparent that regional migrations (especially region to region) exceed outward emigration.

Table 1

International and Regional Migrations in the Czech Republic (total, 2000-2010)

\begin{tabular}{|c|c|c|c|c|c|c|c|c|c|c|c|}
\hline \multicolumn{12}{|c|}{ International migration } \\
\hline & 2000 & 2001 & 2002 & 2003 & 2004 & 2005 & 2006 & 2007 & 2008 & 2009 & 2010 \\
\hline Immigrants & 7802 & 12918 & 44679 & 60015 & 53453 & 60294 & 68183 & 104445 & 77817 & 39973 & 30515 \\
\hline Emigrants & 1263 & 21469 & 32389 & 34226 & 34818 & 24065 & 33463 & 20500 & 6027 & 11629 & 14867 \\
\hline Net migration & 6539 & -8551 & 12290 & 25789 & 18635 & 36229 & 34720 & 83945 & 71790 & 28344 & 15648 \\
\hline \multicolumn{12}{|c|}{ Internal migration } \\
\hline & 2000 & 2001 & 2002 & 2003 & 2004 & 2005 & 2006 & 2007 & 2008 & 2009 & 2010 \\
\hline $\begin{array}{l}\text { Region to } \\
\text { region }\end{array}$ & 53333 & 62593 & 70921 & 67146 & 67679 & 75669 & 81354 & 98403 & 97914 & 91865 & 91740 \\
\hline
\end{tabular}

Source: Czech Statistical Office, 2012. 
Vavrejnová (2004) suggests that up to now the decisive factor of the low regional migrations has been badly-functioning housing-stock market. Privatization of state-owned apartments, especially selling apartments in the regions with high unemployment has contributed to "chaining" local labour force in these regions and helping to spreading the speculations with those apartments (this, in its turn, leads to decreasing of available housing stock for the social cases). In spite of privatization, private apartments still constitute $53.7 \%$ of the housing stock in the Czech Republic (Czech Statistical Office, 2011).

Table 2 depicts the migration increase/decrease on the NUTS 2 level (regions for statistical purpose in the Czech Republic called oblast in Czech language). One can see that while the most economically developed oblasts of Prague and especially Central Bohemia are marked by high migration inflows, Central Moravia and especially Moravia-Silesia show quite the opposite trend. The issue of Silesia, which represents a special sub-region with strong historic and cultural peculiarities, is of a specific nature and is also discussed in the sub-section describing regional migrations in Poland.

Table 2

Migration Increase/Decrease per 1,000 people on the NUTS 2 Level (oblast) in the Czech Republic in 2005-2010 (in \%)

\begin{tabular}{|l|r|r|r|r|r|r|}
\hline & $\mathbf{2 0 0 5}$ & $\mathbf{2 0 0 6}$ & $\mathbf{2 0 0 7}$ & $\mathbf{2 0 0 8}$ & $\mathbf{2 0 0 9}$ & $\mathbf{2 0 1 0}$ \\
\hline PRAGUE & 10.0 & 5.3 & 19.2 & 15.5 & 11.0 & 4.5 \\
\hline CENTRAL BOHEMIA & 12.8 & 14.1 & 20.6 & 21.3 & 11.6 & 11.7 \\
\hline SOUTHWEST & 3.9 & 4.4 & 7.3 & 8.5 & 2.0 & 0.2 \\
\hline NORTHWEST & 0.8 & 0.0 & 8.2 & 3.4 & -1.3 & -0.8 \\
\hline NORTHEAST & 2.6 & 3.1 & 5.0 & 4.8 & 0.6 & 0.3 \\
\hline SOUTHEAST & 1.2 & 1.8 & 5.4 & 3.4 & 1.3 & 0.5 \\
\hline CENTRAL MORAVIA & 0.1 & 0.5 & 1.8 & 0.0 & -0.7 & -1.0 \\
\hline MORAVIA-SILESIA & -1.3 & -1.0 & -0.1 & -0.1 & -2.3 & -3.2 \\
\hline
\end{tabular}

Source: Czech Statistical Office, 2012.

An interesting fact is that change of the workplace and moving closer to the workplace are the most irrelevant factors of the regional migrations. In 1999, when the unemployment rate in the Czech Republic was about $8.5 \%$, these two reasons made $6 \%$ of the total regional migration turnover and remained on the same scale even when migration had risen to $10 \%$ in 2002 (Czech Statistical Office, 2004). Nowadays, with unemployment rate as high as $7.3 \%$, the rate of regional migrations declined even further.

\subsection{International and regional migration in Poland}

Migration is the socio-economical phenomenon that is the significant part of the Polish history. After the collapse of the Iron Curtain, the scale of mobility did not change remarkably but changes in mobility's form and structure were observed. In the late 1980s, the phenomenon of incomplete migration was coined (Okólski, 2001 and 
2009). It developed in the next decade becoming in that time the most popular form of international migration in Poland. Migrants usually left Poland only temporarily (officially with the tourist status) and aimed mainly for Germany and Italy where they were unofficially employed in low-skilled sectors of labour market. During that time, inter-regional diversity in the scale of phenomenon was observed. In some regions (i.e. Podlasie, Podhale), even $70 \%$ of migrants were incomplete migrants (Kaczmarczyk and Tyrowicz, 2008).

Accession of Poland to the European Union in 2004 resulted in new institutional regulations (Grabowska-Lusińska and Okólski, 2009). Despite the fact that the accession to the labour markets of old Member States was restricted (only the UK, Ireland and Sweden opened labour markets for Poles in 2004), Poland experienced the mass outflow of its citizens. According to the British Office for National Statistics (2011), the number of Poles in the United Kingdom was about 550 thousand people in 2011, the secondlargest group of foreign-born immigrants after Indians (693 thousand), and followed by Pakistani (433 thousand) and Irish (406 thousand). In Ireland, Poles constituted more than 57 per cent of all foreign workers residing in the country (Wiśniewski and Duszczyk, 2006). Among different drivers that also may cause an interest in emigration in Poland are the high unemployment rate (according to the World Bank in 2004 in Poland 19\%, in the Czech Republic 9.1\% and in EU countries 9.1\%) and relatively low wages in comparison with old EU Member States. ${ }^{2}$

The majority of migrants went abroad without reporting the length of their stay. This fact caused problems in precise monitoring the scale of phenomenon. Figure 2 presents permanent migration flows from and to Poland after the fall of communism in 1989.

The statistics of permanent migration flows bases on register data that by their nature are highly underestimated (Kaczmarczyk, 2011). Estimates of Polish Statistical Office based on Polish LFS and Census data claim that the stock of Poles abroad increased from 1 million in 2004 to 2.27 millions in 2007 and then, mainly due to the economical crisis, started to decrease.

Poland is the one among the five (Romania, Bulgaria, Lithuania and Latvia) EU countries where immigration is still the incidental phenomenon (Okólski, 2009). Despite the systematic improvement of the economical situation, Poland is still not perceived as attractive for immigrants. However, it is worth noting the increasing trend from the beginning of the 2000s in registered immigration to Poland (Kaczmarczyk, 2011). Among permanent as well as temporary immigrants in Poland dominates citizens of Ukraine, Russia, Belarus, Vietnam and Germany.

2 It is worth noting that throughout recent history, economic conditions on the labour market in Poland were considerably worse than in the Czech Republic. The unemployment rate was higher in Poland since the fall of the Iron Curtain (about 1.5-2 times higher). In addition, all throughout the 20th century Poland displayed significantly lower living standards of population (the Czech Republic and south-west regions of Poland already belonged to the most economically advanced parts of Europe before the World War II). Consequently, migration networks and migratory tradition in those regions in the time of EU accession were not cultivated. 
Figure 2:

Gross Migration Flow (permanent): Republic of Poland (1989-2010)

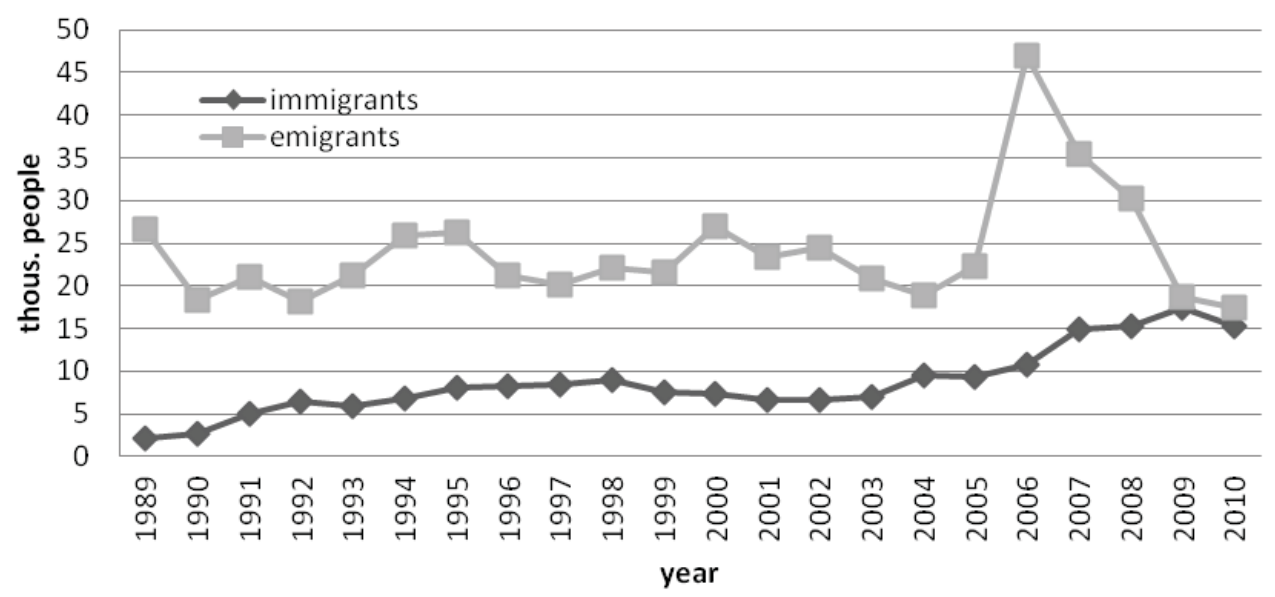

Source: Polish Statistical Office, 2012.

In case of regional migration in Poland, some authors (Ghatak, 2008; Wolszczak-Derlacz, 2009) claim that internal migration across 16 main Polish regions (voivodeships) is relatively low by international standards. From 1995, the number of internal registered migrants varies from 95 to 115 thousands per year (Polish Statistical Office, 2011). But, similarly as for international migration, we face the problem of the lack of reliable data on internal migration flows and it may be expected that the scale of the phenomenon is significantly bigger.

In accordance with the Census 2002 (GUS 2003), around 60\% of Poles never changed their place of residence or did not leave it for more than 1 year. This phenomenon is mostly observed in South-Eastern regions of Poland where it exceeds 67\% (Małopolskie, Podkarpackie, Świętokrzyskie). The opposite situation is in the North-Western regions that it drops under 50\% (Zachodniopomorskie). Internal migration flows were observed mainly from south to north and from cities to bigger (or other) cities.

According to the research on the determinants of internal migration flows in Poland done by Ghatak et al. (2008), the strong effect on regional migration in Poland have mainly economic factors such as GDP per capita and unemployment. However, the strong effect have also distance, human capital and the lack of housing in the country. The economic situation changed significantly during last two decades in the whole country (the income gap between Poland and the richest EU Member States systematically decreased, unemployment rate varied from around $20 \%$ to around $8 \%$ ) and disparities between regions even increased creating better conditions for inter-regional migration. 
Table 3

International and Regional Migrations in Poland (total, 2000-2010)

\begin{tabular}{|c|c|c|c|c|c|c|c|c|c|c|c|}
\hline \multicolumn{12}{|c|}{ International migration } \\
\hline & 2000 & 2001 & 2002 & 2003 & 2004 & 2005 & 2006 & 2007 & 2008 & 2009 & 2010 \\
\hline Immigrants & 7331 & 6625 & 6587 & 7048 & 9495 & 9364 & 10802 & 14995 & 15275 & 17424 & 15246 \\
\hline Emigrants & 26999 & 23368 & 24532 & 20813 & 18877 & 22242 & 46936 & 35480 & 30140 & 18620 & 17360 \\
\hline Net migration & -19668 & -16743 & -17945 & -13765 & -9382 & -12878 & -36134 & -20485 & -14865 & -1196 & -2114 \\
\hline \multicolumn{12}{|c|}{ Internal migration by type } \\
\hline & 2000 & 2001 & 2002 & 2003 & 2004 & 2005 & 2006 & 2007 & 2008 & 2009 & 2010 \\
\hline Region to region & 394120 & 403600 & 432189 & 414137 & 432070 & 431275 & 473622 & 461471 & 405981 & 382688 & 392071 \\
\hline
\end{tabular}

Source: Polish Statistical Office, 2012.

Additionally, there are observed significant differences in the scale of the phenomenon on the regional level. Table 3 presents international and adjusted regional migrations observed on NUTS 2 level (voivodeships) from 2000 to 2010. The bigger differences between regions are observed in case of international than inter-regional migration that was especially prominent immediately after the EU Accession. The real migration outflows are likely to be bigger but are not reported due to the way statistics are collected by the Polish Statistical Office. For instance, according to the U.K. Office for National Statistics in 2011 alone there were 614,000 Poles living and working in the UK (in comparison with 32,000 Czechs), while some sources report a number exceeding one million persons (Office for National Statistics, 2012).

It is apparent from Table 4 that international and inter-regional migrations are not always comparative and in some regions only one type of migration plays a crucial role. There are only several regions (e.g. Mazowieckie or Wielkopolskie voivodeships) that have similar ranks in case of both types of migration. Much more often a high rank in international (inter-regional) migration coincides with low rank in inter-regional (international) migration.

The most specific is the case of Silesia region (Śląskie and Opolskie voivodeships) where we observe the highest ranks in international and relatively low ranks in inter-regional migration. These two voievodeships belong to Silesia Euroregion that is currently located in both countries: Poland and the Czech Republic. Inhabitants of these parts of Poland identify themselves stronger with the region than any country that was proved during the Census 2011 when 400 thousand Poles declared the Silesian instead of Polish, German or Czech nationality.

The additional problem related to Silesia is the fact that after the World War II several millions Germans were expelled out of Poland and Czechoslovakia (mainly from Silesia) and that caused resettlement inside both countries. People living in Silesia have strong links to Germany developed throughout the $20^{\text {th }}$ century which might explain why they are much more interested in international than in internal migration. 
Table 4

Migration Increase/Decrease per 1,000 People on the NUTS 2 Level (voivodeship) in Poland in 2005-2010 (in \%)

\begin{tabular}{|l|c|c|c|c|c|c|}
\hline & $\mathbf{2 0 0 5}$ & $\mathbf{2 0 0 6}$ & $\mathbf{2 0 0 7}$ & $\mathbf{2 0 0 8}$ & $\mathbf{2 0 0 9}$ & $\mathbf{2 0 1 0}$ \\
\hline ŁÓDZKIE & -0.7 & -1.1 & -0.8 & -0.7 & -0.5 & -0.7 \\
\hline MAZOWIECKIE & 2.9 & 3.0 & 2.9 & 2.2 & 2.4 & 2.6 \\
\hline MAŁÓPOLSKIE & 1.0 & 0.4 & 0.8 & 0.7 & 1.3 & 1.3 \\
\hline ŚLĄSKIE & -1.9 & -2.6 & -2.1 & -1.5 & -1.0 & -1.1 \\
\hline LUBELSKIE & -2.2 & -3.0 & -2.7 & -2.1 & -1.9 & -2.3 \\
\hline PODKARPACKIE & -1.1 & -1.9 & -1.5 & -1.1 & -0.9 & -0.9 \\
\hline PODLASKIE & -1.6 & -2.4 & -2.1 & -1.4 & -1.4 & -1.3 \\
\hline ŚWIĘTOKRZYSKIE & -1.8 & -2.7 & -2.3 & -1.8 & -1.7 & -2.0 \\
\hline LUBUSKIE & -0.6 & -1.6 & -1.2 & -0.7 & -0.5 & -0.5 \\
\hline WIELKOPOLSKIE & 0.7 & 0.2 & 0.6 & 0.3 & 0.5 & 0.4 \\
\hline ZACHODNIOPOMORSKIE & -1.0 & -1.1 & -1.0 & -0.8 & -0.5 & -0.6 \\
\hline DOLNOŚLĄSIE & -0.6 & -1.3 & -0.5 & -0.4 & 0.3 & 0.5 \\
\hline OPOLSKIE & -3.0 & -4.6 & -3.9 & -3.2 & -1.7 & -1.7 \\
\hline KUJAWSKO-POMORSKIE & -1.0 & -1.7 & -1.1 & -0.8 & -0.7 & -0.8 \\
\hline POMORSKIE & 0.5 & -0.4 & 0.6 & 0.6 & 1.2 & 1.2 \\
\hline WARMIŃSKO-MAZURSKIE & -2.2 & -3.5 & -2.7 & -2.2 & -2.0 & -1.9 \\
\hline
\end{tabular}

Source: Polish Statistical Office, 2012.

\section{Data and Methodology}

We conducted a comparative study of two countries: the Czech Republic and Poland in order to demonstrate the dependence of migration flows on the economic factors and analyse the migration potential. We analyse the migration potential measured by the number of migrants from and to the administrative regions of the two selected countries as a reaction to the economic incentives such as expected income and employment structure within each state.

To our mind, Poland is distinguished by the high migration potential and Polish labour force reacts quickly to the economic changes at home and incentives elsewhere. Polish population has been marked by a high rate of emigration throughout the last century subject to the worsening conditions at home. On the other hand, we suspect that in the Czech Republic the migration potential is low given the local specifics and the heritage of the Communist economy.

The data cover the period of 2000-2010 for the Czech Republic and 1999-2010 for Poland $^{3}$. The data represent the observations of average monthly salary corrected by

3 We take this period to clean off the data from disturbances caused by the post-socialist period that was indicated by increased short-term migration to the West. This period is also interesting due to the effects of EU enlargement in 2004. 
the tax transfers by regions and employment structure (unemployment rate) according to main sectors of economy. We also included GDP per capita for each region and performed the analysis with and without it.

Most of the data were obtained from the Czech Statistical Office and the Polish Statistical Office. The regional data from Poland and the Czech Republic are divided by regions ('kraje' in Czech, 14 regions in whole) in the Czech Republic and voivodeships ("wojewodstwa" in Polish, 16 in whole) in Poland.

The data report overall immigration and emigration per region, without distinguishing the regions of origin or destination of migrants. The fact that the data report migration of populations rather than labour migration may cause problems when interpreting the results, but this is a problem of all migration studies and is subjected to the availability of the data.

\section{Empirical Model: Main Results and Discussion}

According to Fidrmuc (2002) migration can be one of the principal mechanisms for absorbing asymmetric shocks. A region hit by, say, negative demand shock will face increasing unemployment and decreasing wages. There are several ways to absorb this shock: for instance, residents of the regions can move to the region with higher wages and lower unemployment; or lower wages can attract potential investors.

We compare the emigration potentials of Poland and the Czech Republic by measuring the responsiveness of regional flows to respective regional economic characteristics. The dependent variables are gross and net migration flows. The data record the total number of migrants arriving to or leaving the region in a given year without any special regard to their destination. We assume that in order for the country's population to have strong migration potential, net immigration should be positively related to corrected average monthly salary ${ }^{4}$ and negatively to unemployment, while gross emigration should be positively related to unemployment and negatively to corrected salary. The vice versa situation suggests the existence of immobile population which does not react to asymmetric shocks.

The formal model is based on similar studies by Geary and O'Grada (1989) and Strielkowski and O'Donoghue (2006). The model can be presented in the following way:

$$
N M_{h}=\beta_{0}+\beta_{1} \text { CORSAL_ } Y_{h}+\beta_{2} \text { EMPSTR_Y } Y_{h}+u_{i} \quad i=1,2, \ldots n
$$

where $\mathrm{NM}$ is the emigration/immigration and net migration flows (total numbers of migrants arriving/leaving a region in a given time period without identifying the destination) normalized by population and the dependent variables: CORSAL_ $\mathrm{Y}_{\mathrm{h}}$ and EMPSTR_ $\mathrm{Y}_{\mathrm{h}}$ represent regional economic characteristics, such as corrected average

4 We chose the corrected average monthly salary instead of disposable income due to the fact that disposable income in the Czech Republic has very minimal regional differences due to secondary distribution of income and may weaken migration in the country. 
salary per capita and the employment structure (represented by average rate of unemployment in the given region). We expect both employment and average salary to have a disproportional relationship with respect to emigration.

In order for migration to be effective as a channel of regional adjustment, gross (and net) immigration should be positively related to both corrected average salary and employment, while emigration should be negatively related to employment and corrected average salary. Table 5 summarizes our relevant findings for the case of the Czech Republic:

Table 5

Determinants of Regional Migration: the Czech Republic (2000-2010)

\begin{tabular}{|l|c|c|c|}
\hline & Immigration & Emigration & Net migration \\
\hline Corr. average salary & $\begin{array}{c}-.531^{* * *} \\
(.034)\end{array}$ & $\begin{array}{c}1.505^{\star * *} \\
(.297)\end{array}$ & $\begin{array}{c}-.939^{* * *} \\
(.174)\end{array}$ \\
\hline Employment structure & $\begin{array}{c}1512.504^{* *} \\
(441.946)\end{array}$ & $\begin{array}{c}-546.232^{* * *} \\
(288.906)\end{array}$ & $\begin{array}{c}969.065^{* *} \\
(228.002)\end{array}$ \\
\hline Constant & $\begin{array}{c}-14838.508^{* *} \\
(7803.646)\end{array}$ & $\begin{array}{c}-8791.96^{*} \\
(5191.37)\end{array}$ & $\begin{array}{c}-5881.45 \\
(4025.96)\end{array}$ \\
\hline R-squared & 0.73 & 0.59 & 0.57 \\
\hline Adjusted R-squared & 0.71 & 0.57 & 0.53 \\
\hline No. of observations & & 154 \\
\hline
\end{tabular}

Note: * significant at 10\%; ${ }^{* *}$ significant at $5 \% ;{ }^{* * *}$ significant at $1 \%$. Standard errors are shown in parentheses. Source: own calculations.

The results show that the pattern that we can obtain for migration in the Czech Republic does not meet the criteria for migration being effective as a channel of regional adjustments.

At the regional level, the unemployment rate in the regions of the Czech Republic is not a significant driver of migration flows. Emigration is negatively related to unemployment indicating that the higher is unemployment, the lower is emigration. Although the coefficients of corrected average salary as an independent variable for immigration and emigration (between regions) are highly significant, they also indicate that an increase in average salaries would increase emigration which is quite opposite what one would expect from economic rationale. Immigration responsiveness to worsening economic conditions at home simply does not work well for the case of the Czech Republic.

We also run the model specified in (1) using the Polish data for 1999-2010. Table 6 summarizes the determinants of regional migrations in the case of Poland: 
Table 6

Determinants of Regional Migration: Poland (1999-2010)

\begin{tabular}{|l|c|c|c|}
\hline & Immigration & Emigration & Net migration \\
\hline Corr. average salary & $\begin{array}{c}16.900^{* * *} \\
(3.917)\end{array}$ & $\begin{array}{c}-2.999^{* *} \\
(1.911)\end{array}$ & $\begin{array}{c}13.686^{* * *} \\
(3.145)\end{array}$ \\
\hline Employment structure & $\begin{array}{c}221.735^{*} \\
(158.889)\end{array}$ & $\begin{array}{c}57.433^{* *} \\
(77.560)\end{array}$ & $\begin{array}{c}-164.3^{* *} \\
(127.595)\end{array}$ \\
\hline Constant & $\begin{array}{c}3995.417 \\
(5045.246)\end{array}$ & $\begin{array}{c}9278.753 \\
(2462.823)\end{array}$ & $\begin{array}{c}-13274.2 \\
(4051.606)\end{array}$ \\
\hline R-squared & 0.41 & 0.62 & 0.43 \\
\hline Adjusted R-squared & 0.38 & 0.58 & 0.39 \\
\hline No. of observations & & 192 & \\
\hline
\end{tabular}

Note: * significant at 10\%; ${ }^{* *}$ significant at $5 \%$; ${ }^{* *}$ significant at $1 \%$. Standard errors are shown in parentheses.

Source: own calculations

Looking at the results obtained for Poland, one can see that the coefficients of corrected average salary and employment are significant and are respectively positively and negatively related to immigration and emigration which is in accordance with accepted economic rationale. The signs of the coefficients are the opposite then in the case of the estimations for the Czech Republic. These results imply that Polish population is mobile and promptly responds to regional asymmetric shocks. It also suggests that the Poles react to the changes in economic incentives within a region. In each case, we see that provincial income differentials are less important than employment structure differentials, which are highly significant, in driving migration. While this may be due to the fact that there is no inter-temporal variation in this variable (merely inter-regional variation), it may indicate that individuals migrate more in search of work than in search of a higher standard of living.

The comparison of regional migrations in the Czech Republic and Poland leads us to two basic conclusions: first, in comparison with the Poles, Czechs do not react to the incentives or worsening of the conditions throughout the country and internal migrations are effected by other factors than economic incentives in the neighbouring region. The second conclusion is that in some cases (i.e. worsening economic conditions at the place of immediate residence) people in the Czech Republic might decide to stay and explore some other alternatives than migration rather than moving to some other region for work. The Poles, under the same conditions, would have chosen emigration (at least a temporal one) which was very much proved by the wave of Polish migration after the EU 2004 enlargement.

In short, there are two countries, the Czech Republic and Poland, with wide differences in migration potential and migration experience. Our analysis shows that the migration potentials differ greatly for each one. It appears that people in some countries are just what we call "mobile" while people in the other countries are not. This mobility can 
be used as a good proxy, in some cases, especially for politicians who often take the decisions about restricting labour mobility based on populism or political lobbying of the groups that are made better of by putting barriers to cheap labour (e.g. trade unions) rather than on research reports and policy implications.

\section{Conclusions and Discussions}

Our analysis that employed the example of two countries, Poland and the Czech Republic, clearly showed that the main driving factors of migration, especially labour migration, are economic. Apart from that there is a migration potential or "propensity to migration" described by the "indicator of migration costs" that might play a crucial role in determining the migration potential and inducing outgoing international migrations. Our results suggest that given same (or slightly) similar wage differentials, Poles might tend to have lower "indicator of migration costs".

Our analysis comparing the relationship of net migration, emigration and immigration with income and employment structure in the regions for the Czech Republic and Poland shows that migration potential of population of these two countries varies considerably: regions with favourable economic conditions tend to experience high immigration as well as emigration, whereas depressed regions display generally low labour mobility. Our findings suggest that this variation will be in favour of countries with more "mobile" population such as Poland. More "mobile" population measured in regional emigration and immigration responsiveness to the changing economic conditions at home might mean that economic incentives abroad as well as opening of new foreign labour markets will very likely lead to larger migration of labour searching for higher wages and employment opportunities. There is no doubt that there is a wide scale of factors, not just economic ones that can affect migrations: social and cultural factors (such as habits and language), housing stock and demographic characteristics and many more that can be considered in this type of analysis.

Our analysis partly explains why Poland can be considered to be the country with a higher migration potential than the Czech Republic. It also provides grounds for explaining high outflows of Poles to some EU countries after the EU 2004 enlargement.

\section{References}

Arltová, M., Langhamrová, J. (2010), "Migration and Ageing of the Population of the Czech Republic and the EU Countries". Prague Economic Papers, Vol. 19, No. 1, pp. 54-73.

Austrian Labour Statistics (2003), "Internationale Wanderungen”. Available online at: http://www. statistik.at/web_de/statistiken/bevoelkerung/wanderungen/internationale_wanderungen/index.html.

Austrian Statistical Office (2011), "Internationale Wanderungen”. Available online at: http://www. statistik.at/web_de/static/internationale_zu-_und_wegzuege_2007-2010_nach_ausgewaehlter_ staatsangehoe_022923.xlsx. 
Borjas, G. (1999), Heaven's Door: Immigration Policy and the American Economy. Princeton University Press.

Czech Statistical Office (2004), "Obyvatelstvo: Časové řady“. Available at: http://www.czso.cz/csu/ redakce.nsf/i/oby_cr.

Czech Statistical Office (2011), "Česká republika v číslech 2010“. Available at: http://www.czso.cz/ csu/2010edicniplan.nsf/t/ED00382D50/\$File/14091017.xls.

Czech Statistical Office (2012), "Statistické ročenky České republiky 2000-2011“. Available at: www.czso.cz.

Cushing, B. (1993), "The Effect of the Social Welfare System on Metropolitan Migration in the US, by Income Group, Gender and Family Structure." Urban Studies, Vol. 30, No 2, pp. 325-337.

De Haas, H. (2005), "International Migration, Remittances and Development: Myths and facts." Third World Quarterly, Vol. 26, No. 2, pp. 1269-1284.

De Jong, G., et al. (1983), "International and Internal Migration Decision-Making." International Migration Review, Vol. 17, No. 3, pp. 470-484.

Dorigo, G., Tobler, W. (1983), "Push-Pull Migration Laws". Annals, Assn. Am. Geographers, (1983), 73 (1): pp. 1-17.

Drbohlav, D., Medová. L., Čermák, Z., Janská, E., Čermáková, D., Dzúrová, D. (2010), Migrace a (i)migranti v Česku. Kdo jsme, odkud přicházíme, kam jdeme? Praha: Sociologické nakladatelství, 2010.

Faini, R., De Melo, J., Zimmermann, K. (1999), Migration: The Controversies and the Evidence. Cambridge, U. K: University of Cambridge, 1999.

Fidrmuc, J. (2002), "Migration and Regional Adjustment to Asymmetric Shocks in Transition Economies". CPB Discussion Paper 007.

Geary, P., O'Grada, C. (1989), Postwar Migration between Ireland and the UK“. In Gordon, I., Thirlwall, A. P. (eds.), European Factor Mobility: Trends and Consequences. Macmillan, 1989.

German Statistical Office (2003), "Labour Market Statistics." Avalable at: www.destatis.de

Ghatak S., Mulhern A., Watson J. (2008), "Inter-Regional Migration in Transition Economies: The Case of Poland." Review of Development Economics, No 12(1), pp. 209-222.

Glazar, O., Strielkowski, W. (2010), "Turkey and the European Union: Possible Incidence of the EU Accession on Migration Flows." Prague Economic Papers, Vol. 19, No. 3, pp. 218-235.

Główny Urząd Statystyczny (2003), "Migracje wewnętrzne ludności 2002". Warszawa, 2003.

Grabowska-Lusińska I., Okolski M. (2009), Emigracja ostatnia? Warszawa: Wydawnictwo Naukowe Scholar, 2009.

Harris, J. R., Todaro, M. P. (1970), "Migration, Unemployment and Development: A Two Sector Analysis". American Economic Review 60 (1): pp. 120-142.

Jaźwińska E. (2001), "Migracja niepełna ludności Polski: zróżnicowanie międzyregionalne." In E. Jaźwińska, M. Okólski (eds.), Ludzie na huśtawce. Migracje między peryferiami Polski i Zachodu. Warszawa: Scholar, pp. 101-124.

Kaczmarczyk, P. (2011), "Polska jako kraj emigracji i imigracji." In P. Kaczmarczyk (ed.), Mobilność i migracje w dobie transformacji. Wyzwania metodologiczne. Warszawa: Scholar 2011: pp. 14-37.

Kaczmarczyk, P., Tyrowicz J. (2008), "Migracje niepełne, Fundacja Inicjatyw SpołecznoEkonomicznych", Warszawa.

Kicinger A., Weinar A., eds. (2007), "State of the Art of the Migration Research in Poland", CMR Working Paper No. 26/84.

Office for National Statistics (2011), "Migration Statistics Quarterly Report". November 2011. Available online: http://www.ons.gov.uk/ons/rel/migration1/migration-statistics-quarterly-report/ november-2011/population-by-country-of-birth-and-nationality.xls. 
Office for National Statistics (2012), "Migration Statistics Quarterly Report". May 2012. Available online: http://www.ons.gov.uk/ons/rel/migration1/migration-statistics-quarterly-report/may-2012/ population-by-country-of-birth-and-nationality.xls.

Okólski M. (2001), "The Transformation of Spatial Mobility and New Forms of International Population Movements: Incomplete Migration in Central and Eastern Europe." In J. Dacyl (ed.), Challenges of Cultural Diversity in Europe. Stockholm: CEIFO: pp. 57-109.

Okólski, M. (2009), "Polska jako aktor na europejskiej scenie migracyjnej." In M. Duszczyk, M. Lesińska (eds), Współczesne migracje. Dylematy Europy i Polski. Warszawa 2009: pp. 7-14.

Ravenstein, E. G. (1885), "The Laws of Migration". Journal of the Statistical Society of London, Vol. 48, No. 2. (June, 1885), pp. 167-235.

Ravenstein, E. G. (1876), "The Birthplace of the People and the Laws of Migration”. The Geographical Magazine, Vol. 3: pp. 173-177, 201-206, 229-233.

Stojanov, R., Strielkowski, W., Drbohlav, D. (2011), "Labour Migration and Remittances: Current Trends in Times of Economic Recession“. Geografie, 116 (4): pp. 375-400.

Strielkowski, W., O’Donoghue. C. (2006), "Ready to Go? EU Enlargement and Migration Potential: Lessons for the Czech Republic in the Context of Irish Migration Experience". Prague Economic Papers, Vol. 15, No. 1, pp. 14-28.

Strielkowski, W., Turnovec, F. (2011), "Neo-Classical Model of Labour Mobility between Two Countries Revisited: Introduction of the Concepts of Propensity to Migration and the Indicator of Migration Cost". Economics and Management, 8 (70): pp. 3-16.

Strielkowski, W. (2012), "Migration in the Czech Republic and Slovakia: An Economic Analysis". Charles University in Prague, Faculty of Social Sciences.

Todaro, M. P. (1969), "A Model of Labour Migration and Urban Unemployment in Less Developed Countries." American Economic Review, 59 (1): pp. 138-148.

Vavrejnova, M. (2004), "Mobilita pracovní síly před a po vstupu ČR do EU." CERGE, UK v Praze.

VÚPSV (2001), "Závěrečná zpráva: "Důsledky vstupu ČR do EU na vztahy s Rakouskem se zaměřením na zaměstnanost, trh práce a migraci." Praha, 2001.

Walsh, B. M. (1974), "Expectations, Information, and Human Migration: Specifying an Econometric Model of Irish Migration to Britain." Journal of Regional Science, Vol. 14, No. 1, pp. 107-120.

Walsh, B. M. (1987), "The Impact of Demographic Variables on Unemployment". In "The Challenge of Unemployment." Administration, Vol. XXXV, No. 3, Dublin.

Wiśniewski, J., Duszczyk, M. (2006), “Migracje zarobkowe Polakow po 1 maja 2004 r.” Report for the Institute of Public Affairs. ISP, Warsaw.

Wolszczak-Derlacz J. (2009), "The Impact of Internal and International Migration on Regional Convergence in Poland." In M. Duszczyk, M. Lesińska (eds), Współczesne migracje. Dylematy Europy i Polski. Warszawa: OBM, 2009, pp. 92-117. 